\title{
THE RECOGNITION OF OUR NATIONAL PARKS AMONG YOUNG
}

\section{ADULTS}

\author{
Éva TÓTH ${ }^{\mathrm{a}}$, \\ ${ }^{a}$ University of Pannonia, Georgikon Faculty, H-8360 Keszthely, Deák F. u. 16, phone: +36-83-545-208, \\ e-mail: te@georgikon.hu
}

Cite this article: Tóth, É. (2015). The Recognition of Our National Parks Among Young Adults. Deturope, 7, 3: 83-100

\begin{abstract}
I conducted a survey questionnaire about the recognition of national parks among the students of the University of Pannonia, Georgikon Faculty in 2012 and 2013. According to my previous experience as a lecturer, I supposed that young people had incomplete knowledge about national parks. As the result of my previous survey about the Danube-Drava National Park Directorate, which is my narrower research area, I had the idea to test the knowledge of young people in a more general questionnaire in the hope of getting a more favourable picture. In order to prove my hypothesis I conducted a survey questionnaire among the students of the Georgikon Faculty who had not met this topic in their university studies yet. 132 students took part in the survey. The research revealed that although young adults had much better knowledge about national parks in general than about one particulate directorate, the results can be improved. According to the results the order of the recognition of national parks can be determined among young people. Young adults like hiking and going on outings in nature but they do not prefer taking part in the programs organized by the national park directorates.
\end{abstract}

Keywords: Hungary national parks, survey, questionnaire, young people, ecotourism

\section{Kivonat}

A nemzeti parkok ismertségével kapcsolatos kérdőíves felmérést készítettem a Pannon Egyetem, Georgikon Kar hallgatóinak körében 2012-ben és 2013-ban. Korábbi oktatói tapasztalataimból kiindulva azt feltételeztem, hogy a felsőoktatásba kerülö fiatalok nemzeti parkokkal kapcsolatos ismeretei hiányosak. Szűkebb kutatási célterületem, a Duna-Dráva Nemzeti Park Igazgatósággal kapcsolatos korábbi kérdőíves felmérésem eredményei láttán jött az ötlet, hogy egy tágabb, általánosabb kérdőívben tesztelem a fiatalok tudását, bízva abban, hogy kedvezőbb képet festenek majd az eredmények. Hipotézisem igazolására kérőíves felmérést készítettem a Georgikon Kar azon hallgatóinak körében, akik a felsőoktatási tanulmányaikban még nem találkoztak a témakörrel. A felmérésben 132 fö hallgató vett részt. A kutatásból kiderül, hogy a fiatal felnőttek nemzeti parkokkal kapcsolatos ismeretei ugyan sokkal jobbak, mint egy konkrét igazgatóság esetében, de még javíthatóak. Az eredmények alapján a nemzeti parkok ismertségének sorrendje is felállítható a fiatalok körében. A fiatal felnőttek szoktak és szeretnek is túrázni, kirándulni a természetben, a nemzeti park igazgatóságok által szervezett programokon azonban nem jellemző a részvételük.

Kulcsszavak: magyar nemzeti parkok, kérdőíves felmérés, fiatal felnőttek, ökoturizmus 


\section{INTRODUCTION}

The main aim of my research is to reveal the knowledge of young people about national parks and their habits concerning hiking. Before starting the survey I set up three hypotheses that can be justified by the results described in the study.

\section{REVIEW OF THE RELEVANT LITERATURE}

\section{National Parks in Hungary}

For the past three decades ten national parks directorates have been established in our country the oldest of them is the Hortobágy National Park Directorate (1973), while the youngest is the Örség National Park Directorate established in 2002. The government decree of 347/2006 (XII 23) appoints the national park directorates establishments, which are responsible for handling protected natural areas in an environmental conscious way. The law includes the responsibilities, headquarters, and activity areas of national park directorates. The present ten national park directorates (NPD), with the year of their establishments, are as follows:

- The Aggtelek NPD (1985),

- Balaton Uplands NPD (1997),

- Bükk NPD (1976),

- Duna-Dráva NPD (1996),

- Duna-Ipoly NPD (1997),
- Fertő-Hanság NPD (1994),

- Hortobágy NPD (1973),

- Kiskunság NPD (1975),

- Körös-Maros NPD (1997),

- The Örség NPD (2002).

I am not going to introduce the Directorates of the National Parks of Hungary in details. Several authors (Kapocsy, 1993; Kalotás, 1996, 2004, 2005, 2008, 2012; Vojnits, 2006), and the publications of the Hungarian Tourism cPlc. and our ministry, (KVvM 2005 then VM 2014), which is responsible for environmental protection, give detailed information about the most important features of our national parks.

The decree of 14/1997. (V 28) by KTM ranked the territories of the national parks into zone categories. $\S 5$ describes the exhibition area, where the exhibition centre can be placed according to the rules determined in the technical plan and the conditions of environment friendly exhibition activities must be ensured here too, that is, sustainable tourism called ecotourism forms here.

\section{Ecotourism}

Unfortunately, ecotourism still does not have a general definition which is accepted internationally. In Hungary its meaning was first determined in the ecotourism section of the Naturexpo conference in 1996 (Lengyel, 1998), according to which on the one hand it is an 
approach, on the other hand it includes the different forms of tourism which are based on natural and cultural attractions. The definition of UNTWO (World Tourism Organization) summarizes the features of ecotourism in five points. Several sources (Sulyok 2001, Cousins 2007, Weaver-Lawton 2007, Ahmad 2014, Sulyok 2014, Mintel 2014) take these into account which can be summarized as follows: nature based tourism with its traditional culture, containing educational and interpretation features, generally organized for small groups from below, it minimizes the negative impacts on the natural and socio-cultural environment, it supports the maintenance of natural areas (with employment and income opportunities for local communities). Ecotourism, has the following definition according to IUCN (International Union for Conservation of Nature), suggested for acceptance as official Hungarian position by the authors' of the National Ecotourism Development Strategy (OÖS): 'ecotourism is a form of travel or visit in relatively undisturbed regions which takes responsibility for the environment in order to enjoy and appreciate the natural and cultural values of the past and present and provide social and economic benefits to the local residents, but these visits moderate the harmful effects'( OÖS,2008, p. 12.). In my opinion the most suitable definition comes from the International Ecotourism Society, which says:' Ecotourism is responsible travel to natural areas that conserves the environment and sustains the well being of local people' (Lindberg, 1993. p. 8.).

The National Ecotourism Development Strategy (2008) characterizes the participants of ecotourism in the following way: they are young and middle aged with higher qualifications and their income is higher than the average. That is why I find it worth examining the potential future demand, that is, young people studying in higher education.

\section{METHODS AND HYPOTHESES}

On the basis of the results in my research area, the Danube-Drava National Park Directorate (Tóth, 2007, 2008, 2010a, 2010b, 2013a), I had the idea to get information about the knowledge of young people in a questionnaire with a more general topic. Besides surveying the available secondary sources about the topic I carried out observations. Having spent several years in education I noticed that university students' knowledge about general geography, at least about national parks is not satisfactory. After my personal experiences I started to gather primary data, which was based on a questionnaire. The works of Majoros (2004), Babbie (2008) and Malhotra (2009) helped me to improve my methodological knowledge. My self-completed, voluntary questionnaire mostly contained open-questions 
besides general personal data. The subjects of my research were the students of the Georgikon Faculty who had not meet this topic in their university studies. The first group of questions of my questionnaire aimed to survey the recognition of national parks, the second part examined their hiking habits.

132 students took part in the survey between the spring semester of 2012 and the autumn semester of 2013. The results were evaluated by Microsoft Office Excel 2003, and SPSS Statistics 17.0 programs. Besides fundamental statistical analysis the categorized variables needed the application of the $\chi^{2}$ test while the correction formula of the Kendall rank concordance coefficient helped to set up the orders of preference.

At the beginning of my research I had the following consumptions:

1 The knowledge of the students in Georgikon Faculty about national parks is insufficient before starting their studies in this field.

2 Students in the Georgikon Faculty go hiking regularly and the majority of them like individual relaxation.

3 The students of the Georgikon Faculty do not often take part in the programs the national park directories offer.

The exposition of the results is listed in the order of my presumed statements.

\section{RESULTS}

$62.8 \%$ of the participants of the survey are women, $31.8 \%$ of them are men, $83.3 \%$ belongs to the age group between 18-25 and the majority has secondary level qualifications. 43.9\% comes from Zala county, $18.2 \%$ from Veszprém county, 7.6\% from Vas county and 6.8\% from Somogy county.

My first question about national parks was: How many national park directorates are there in Hungary? (Fig. 1) 23 people said no (17,4\%), of the others 40 people (30.3\%) gave the correct answer, that is there are ten national park directorates in the country. $23.5 \%$ of the participants answered 9, which is close to the correct answer while the others (52.3\%) guessed between 2 and 15.

The indication of the number of national park directorates does not depend on the gender, age, qualifications, place of living and hiking habits of the participants but it does depend on the time of questioning and this connection is justified by the Pearson $\chi^{2}$. 
Figure 1 How many national park directorates are there in Hungary?

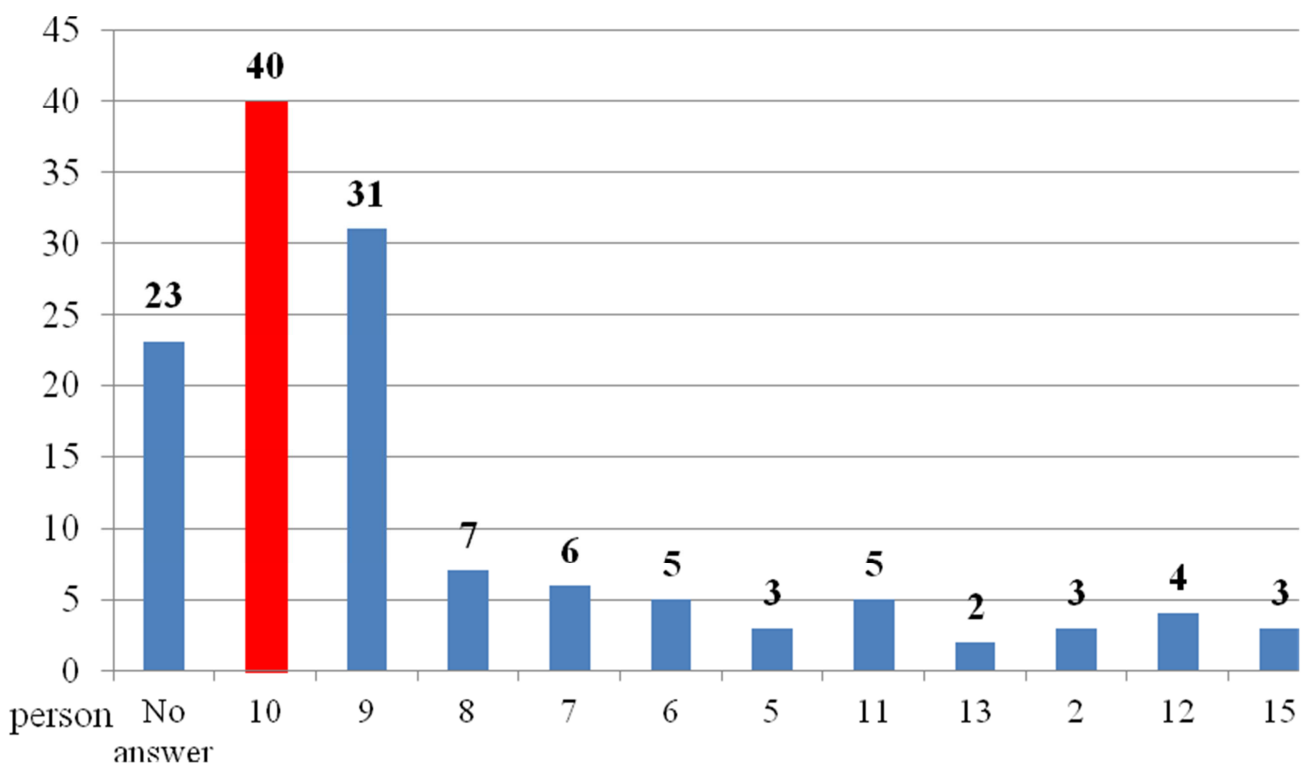

Source: edited by author

In the different semesters the students who made up the sample had very different knowledge.

At a significance level of $0.008 \%$, the value of the Cramer V index is 0.23 , which shows a weak significance connection (Tab. 1). While in both of the semesters of 2012 the majority $(61.5 \%$ and $88.9 \%)$ gave good values $(10)$ or made one mistake $(9,11)$ when answering the questions, in both of the semesters of 2013 the majority gave answers, which had a difference more than one comparing it to the correct answer or they did not answer at all $(52 \%, 57.5 \%)$.

Table 1 Variable indicating significant connection with the number of National Park Directorates

Source: edited by author

\begin{tabular}{|c|c|c|c|}
\hline Criterion & $\chi^{2}$ & Cramer $-\mathbf{V}$ & p \\
\hline Time of questioning & 22,36 & 0,238 & 0,008 \\
\hline
\end{tabular}

It is not sure that there is real knowledge if a number is correct therefore my next question asked them to list the parks. 13 students $(11.4 \%)$ could not mention any of the national park directorates however 17 people $(12.9 \%)$ could list all the NPDs correctly. On average the respondents could name 5.5 NPDs.

Of course nobody listed more than 10, although they mentioned $11,12,13,15$ in the previous answers several times, and it also happened that the respondents named non-existent directorates. Among others the answers included the NPDs of the Great Hungarian Plain, Kis Balaton, Mátra, Lake Fertő, Gemenc and Nagykunság. Fig. 2 shows how well young people know our different national park directorates. 
Figure 2 The frequency of reputation of National Park Directorates

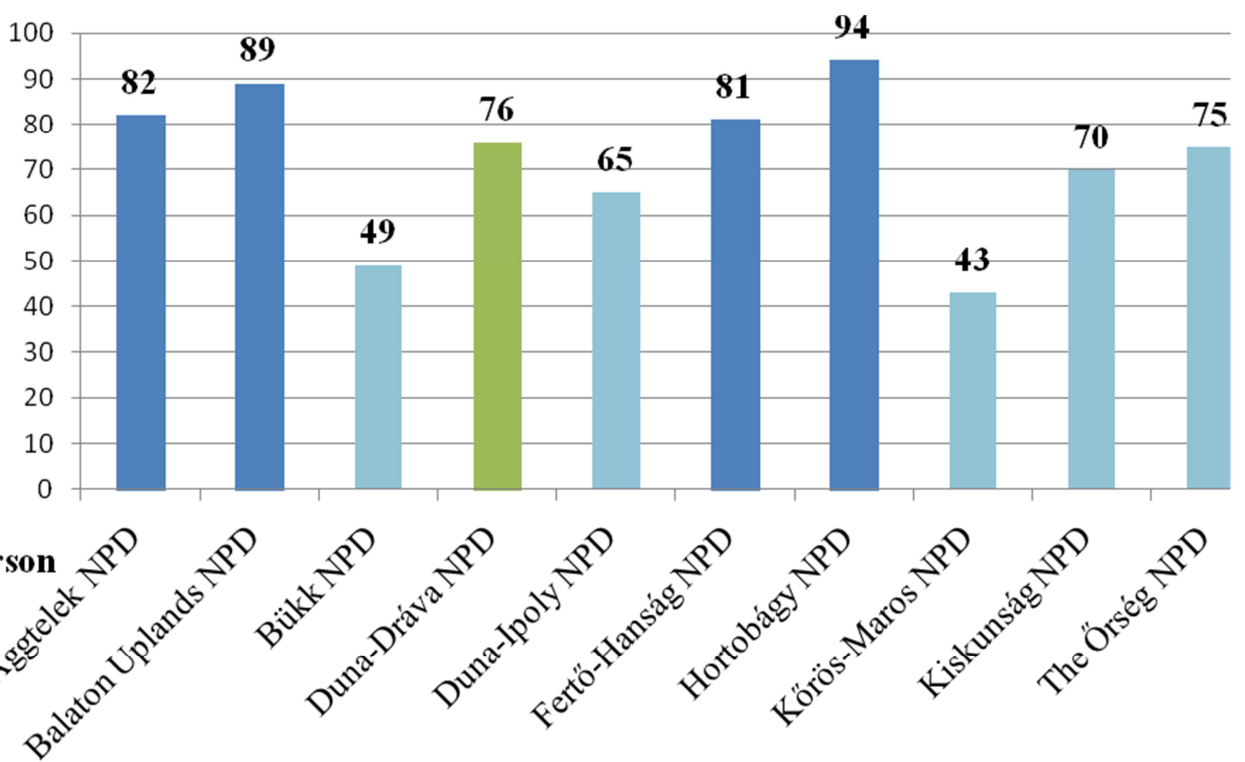

Source: edited by author

We can observe that the Hortobágy National Park Directorate (HNPD) is the most popular. This result is not surprising because this is our largest and oldest national park directorate that celebrated its $40^{\text {th }}$ anniversary in 2013 . It was mentioned by $71.2 \%$ of the interviewees and $80.3 \%$ of the respondents. Hortobágy NPD was followed by Balaton Uplands NPD (BFNPD), Aggtelek NPD (ANPD), and Fertő-Hanság NPD (FHNPD). The fact that BFNPD is well known is not surprising as the majority of the interviewees live in the territory of this directorate and all of them studies in the capital of Lake Balaton in Keszthely. The DanubeDrava National Park Directorate, which is in the centre of my basic research, is placed in the first part of the middle section. Its recognition is satisfactory as more than half of the interviewees $(57.5 \%)$ mentioned it and $65 \%$ of the respondents named it. I also wanted to know whether the recognition of the NPDs changed during the years therefore I examined the relation of the recognition of the NPDs to each other in each semester. It can well be seen that the most popular ones are those which have already been mentioned above, whereas the least known are the Bükk NPD (BNPD) and the Körös-Maros NPD (KMNPD). However the recognition of the Örség NPD grew continuously among the students from semester to semester.

If the NPDs are graded according to the number of their mentioning in each semester, it can be seen clearly that the rate of bonds is high that is the parity of rank numbers is high in the preference order (Tab. 2). 
Table 2 Reference to National Park Directorates and orders of preference

\begin{tabular}{|c|c|c|c|c|c|c|c|c|c|c|}
\hline & $\begin{array}{c}\text { The } \\
\text { Aggtelek } \\
\text { NPD }\end{array}$ & $\begin{array}{c}\text { Balaton } \\
\text { Uplands } \\
\text { NPD }\end{array}$ & $\begin{array}{c}\text { Bükk } \\
\text { NPD }\end{array}$ & $\begin{array}{c}\text { Duna- } \\
\text { Dráva } \\
\text { NPD }\end{array}$ & $\begin{array}{c}\text { Duna- } \\
\text { Ipoly } \\
\text { NPD }\end{array}$ & $\begin{array}{c}\text { Fertö- } \\
\text { Hanság } \\
\text { NPD }\end{array}$ & $\begin{array}{c}\text { Hortobágy } \\
\text { NPD }\end{array}$ & $\begin{array}{c}\text { Körös- } \\
\text { Maros } \\
\text { NPD }\end{array}$ & $\begin{array}{c}\text { Kiskunság } \\
\text { NPD }\end{array}$ & $\begin{array}{c}\text { The } \\
\text { Orség } \\
\text { NPD }\end{array}$ \\
\hline $\begin{array}{c}\text { Spring } \\
\mathbf{2 0 1 2}\end{array}$ & 22 & 30 & 12 & 21 & 19 & 26 & 28 & 15 & 15 & 11 \\
\hline $\begin{array}{c}\text { Autumn } \\
\mathbf{2 0 1 2}\end{array}$ & 13 & 12 & 8 & 13 & 10 & 13 & 16 & 7 & 12 & 12 \\
\hline $\begin{array}{c}\text { Spring } \\
\mathbf{2 0 1 3}\end{array}$ & 32 & 34 & 21 & 27 & 25 & 29 & 35 & 17 & 32 & 35 \\
\hline $\begin{array}{c}\text { Autumn } \\
\mathbf{2 0 1 3}\end{array}$ & 15 & 13 & 8 & 15 & 11 & 13 & 15 & 4 & 11 & 17 \\
\hline $\begin{array}{c}\text { Spring } \\
\mathbf{2 0 1 2}\end{array}$ & 4 & 1 & 9 & 5 & 6 & 3 & 2 & 7,5 & 7,5 & 10 \\
\hline $\begin{array}{c}\text { Autumn } \\
\mathbf{2 0 1 2}\end{array}$ & 3 & 6 & 9 & 3 & 8 & 3 & 1 & 10 & 6 & 6 \\
\hline $\begin{array}{c}\text { Spring } \\
\mathbf{2 0 1 3}\end{array}$ & 4,5 & 3 & 9 & 7 & 8 & 6 & 1,5 & 10 & 4,5 & 1,5 \\
\hline $\begin{array}{c}\text { Autumn } \\
\mathbf{2 0 1 3}\end{array}$ & 3 & 5,5 & 9 & 3 & 7,5 & 5,5 & 3 & 10 & 7,5 & 1 \\
\hline
\end{tabular}

Source: edited by author

In this case the correction formula of the Kendall rank concordance coefficient can be applied in the calculations to establish how much the parity is between the preference orders.

$$
W=\frac{\Delta}{\frac{1}{12} k^{2}\left(n^{2}-n\right)-k \sum L}, \text { where }
$$

$\Delta=\sum_{i}\left(R_{i}-\bar{R}\right)^{2}, \mathrm{k}$ is the number of the existing rank orders, $\mathrm{n}$ is the number of the factors to be

$$
\text { ranked and } L=\frac{\Sigma\left(t^{2}-t\right)}{12}
$$

In our case taking the bond number of each semester into consideration

$$
\begin{gathered}
\sum L=\frac{\left(2^{\mathrm{a}}-2\right)}{12}+\frac{\left(3^{\mathrm{a}}-3\right)+\left(3^{\mathrm{a}}-3\right)}{12}+\frac{\left(2^{\mathrm{a}}-2\right)+\left(2^{\mathrm{a}}-2\right)}{12}+\frac{\left(3^{\mathrm{a}}-3\right)+\left(2^{\mathrm{a}}-2\right)+\left(2^{\mathrm{a}}-2\right)}{12}=\frac{105}{12} \text { and } \Delta=862 \text { from where } \\
W=\frac{862}{\frac{1}{12} 4^{2}\left(10^{\mathrm{b}}-10\right)-4^{105}}=0,671
\end{gathered}
$$

As it can be seen that $67 \%$ of the order of preference is the same regarding each semester. The value of the coefficient is significant because:

$$
\chi^{2}=\frac{124}{k n(n+1)}=\frac{12 \cdot 862}{4 \cdot 10 \cdot(10+1)}=23,51>\chi_{0,99}^{2}=21,7(v=10-1=9)
$$

A parity of $67 \%$ is considered suitable to set up a final order on the basis of the sums of the rank numbers (Tab. 3). 
Table 3 Order of National Park Directorates on the basis of the total of ranking numbers

\begin{tabular}{|c|c|c|c|c|c|c|c|c|c|c|}
\hline & $\begin{array}{c}\text { The } \\
\text { Aggtelek } \\
\text { NPD }\end{array}$ & $\begin{array}{c}\text { Balaton } \\
\text { Uplands } \\
\text { NPD }\end{array}$ & $\begin{array}{c}\text { Büikk } \\
\text { NPD }\end{array}$ & $\begin{array}{c}\text { Duna- } \\
\text { Dráva } \\
\text { NPD }\end{array}$ & $\begin{array}{c}\text { Duna- } \\
\text { Ipoly } \\
\text { NPD }\end{array}$ & $\begin{array}{c}\text { Fertö- } \\
\text { Hanság } \\
\text { NPD }\end{array}$ & $\begin{array}{c}\text { Hortobágy } \\
\text { NPD }\end{array}$ & $\begin{array}{c}\text { Körös- } \\
\text { Maros } \\
\text { NPD }\end{array}$ & $\begin{array}{c}\text { The } \\
\text { Kiskunság } \\
\text { NPD }\end{array}$ & $\begin{array}{c}\text { Órség } \\
\text { NPD }\end{array}$ \\
\hline Ri & 14,5 & 15,5 & 36 & 18 & 29,5 & 17,5 & 7,5 & 37,5 & 25,5 & 18,5 \\
\hline Order & $\mathbf{2}$ & $\mathbf{3}$ & $\mathbf{9}$ & $\mathbf{5}$ & $\mathbf{8}$ & $\mathbf{4}$ & $\mathbf{1}$ & $\mathbf{1 0}$ & $\mathbf{7}$ & $\mathbf{6}$ \\
\hline
\end{tabular}

Source: edited by author

Listing the national parks do not depend on the year of questioning, the gender, the qualifications, the place of living and the hiking habits. It depends on the age and the answers about the number of the NPDs as it can be seen in the connection indicated by the Pearson $\chi^{2}$ significance value.

When the connection between the age and the list of the NPDs was examined we got a 0.35 Cramer V value, which shows a loose significance connection ( $\mathrm{p}=0,020)$ (Tab. 4).

We can conclude that $88.2 \%$ of the respondents who gave a perfect answer (they could list the 10 NPDs) belonged to the age group between 18-25. The rate of non respondents was about $13 \%$ in both groups. While more than the half of the age group between 18 and 25 $(50.8 \%)$ could list 7 or more national park directorates, $50 \%$ of the age group over 25 could name fewer than 5 . therefore we can state that the younger generation has a more precise knowledge.

When I examined the connection between listing the NPDs and the number of the NP directorates, the Cramer $\mathrm{V}=0.44$ value showed medium strong significance connection $(p=0.000)($ Tab. 4). 100\% was achieved by those who said that there were 10 NPDs. However only $42.5 \%$ of the students who knew that there were 10 national park directorates in Hungary could name them precisely while $12.5 \%$ gave 9,8 or 7 correct answers. The two values of $\lambda$ show that the given number of NPDs depends on the success of listing the national parks and not the other way round. $\lambda=0.239(\mathrm{p}=0.003)$, which means that if we know how many national parks someone can list correctly we can improve our chance by $23.9 \%$ to say what number they will write for the number of national parks.

Table 4 Variables indicating significant connections with listing National Park Directorates

\begin{tabular}{|c|c|c|c|}
\hline Criterion & $\chi^{\mathbf{2}}$ & Cramer $-\mathbf{V}$ & $\mathbf{p}$ \\
\hline Age & 16,572 & 0,354 & 0,020 \\
\hline Number of National Park Directorates & 77,459 & 0,442 & 0,000 \\
\hline
\end{tabular}

Source: edited by author 
I asked them whether they know which one the oldest and youngest NPD is. $62 \%$ of the interviewees (81 people) did not know or did not want to name our oldest directorate. 11\% gave the wrong answer, most of them thought that the Aggtelek NPD was the oldest but BFNPD and the Bükk NPD were also mentioned. 36 people (27\% of the interviewees) wrote correctly that the Hortobágy National Park Directorate was our first and at the same time our largest national park directorate (Fig. 3).

Figure 3 Distribution of the name 'oldest National Park'

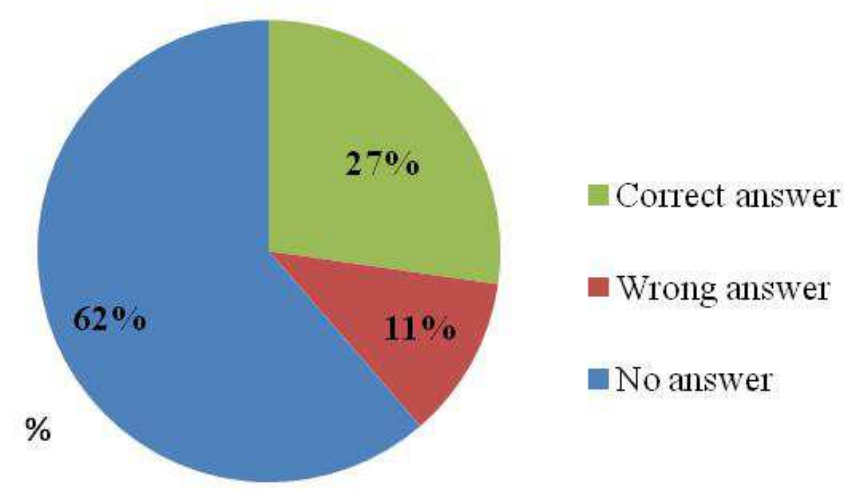

Source: edited by author

The youngest one is the Örség NPD, which got the title in 2002, is not so well-known, 29 people, $22 \%$ gave the correct answer, 5 answers were wrong and almost three quarters of the interviewees did not even answer this question (Fig. 4).

Figure 4 Distribution of the name 'youngest National Park'

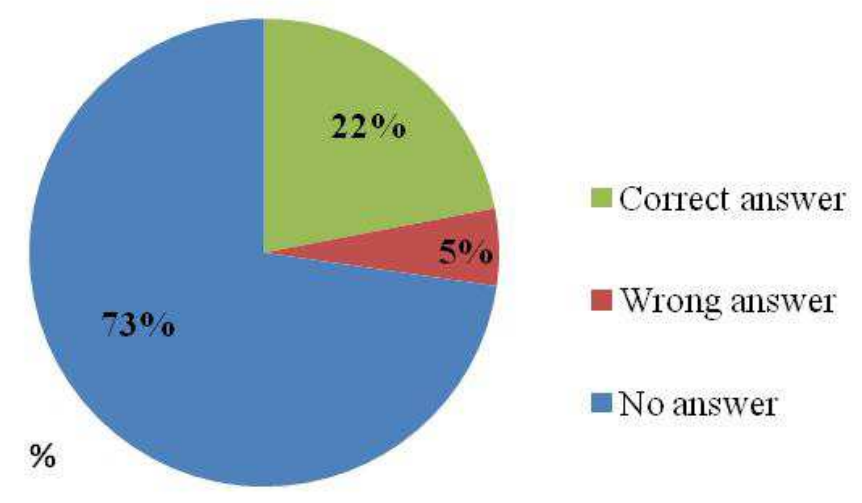

Source: edited by author

Mentioning the oldest national park directorates indicates a significant connection with two variables it depends on whether they could say the number of the national park directorates 
and whether they could name them, the connection is indicated by the Pearson $\chi^{2}$ significance value.

When I examined the connection between naming the oldest NPD and the given number of NPDs the value of the Cramer $V=0.26$ showed a weakly significant connection $(p=0.007)$, (Tab. 5).

The respondents who wrote the numbers of 10,9 or 11 as their answer, gave $80.5 \%$ of the right answers in connection with the oldest national park. $40 \%$ of the respondents who marked number 10 could name the oldest national park, but $47.5 \%$ did not answer. $36.1 \%$ of those who marked 9 or 11 knew HNPD well as the oldest NPD but $56 \%$ of them did not answer. More than one fifth $(21.2 \%)$ of those who gave an answer with a difference more than one gave the wrong answer and $67 \%$ of them did not answer at all. The smaller the difference was from the correct number, the higher the rate of correct answers were and the smaller the rate of non respondents. The interviewees who did not write an answer to the number, did not want to guess therefore they did not answer about the oldest NPD (87\%), although $13 \%$ of them certainly knew that Hortobágy was the oldest NPD.

When I examined the connection between naming the oldest NPD and listing the NPDs the value of Cramer $\mathrm{V}=0.36$ showed a weakly significant connection $(\mathrm{p}=0.001)$ (Tab. 5). $70.6 \%$ of the respondents who could name all the 10 NPDs exactly knew that the Hortobágy NP was the oldest. A large proportion of those who could name 9 NPDs (45.5\%) gave a correct answer. Below this $16-27 \%$ could name the oldest NPD correctly but in these categories most of them did not answer (60-85\%). The rate of wrong answers was between 0 $20 \%$.

Table 5 Variables indicating significant connection with the name 'oldest National Park'

\begin{tabular}{|c|c|c|c|}
\hline Criterion & $\chi^{2}$ & Cramer -V & p \\
\hline $\begin{array}{c}\text { Number of National } \\
\text { Park Directorates }\end{array}$ & 17,716 & 0,259 & 0,007 \\
\hline $\begin{array}{c}\text { List of National Park } \\
\text { Directorates }\end{array}$ & 35,432 & 0,366 & 0,001 \\
\hline
\end{tabular}

Source: edited by author

Naming the youngest national park did not depend on the year of questioning, gender, qualifications, place of living and hiking habits. However it depends on the age and the answer given to the number of NP directorates and the connection is indicated by the Pearson $\chi^{2}$ significance value. 
When I examined the connection between naming the youngest NPD and the age the Cramer $\mathrm{V}=0,20$ value a weakly significant connection $(\mathrm{p}=0.081)$ (Tab. 6). The cross table shows that although $70 \%$ of the age group between 18-25 did not answer, one quarter of them $(25.5 \%)$ gave a correct answer that the ÖNPD was the youngest NPD. On the other hand, $86.4 \%$ of the age group over 25 did not answer and only $4.5 \%$ of them gave a correct answer. It is also approved that the younger generation have a better knowledge just like when they listed the NPDs.

When I examined the connection between naming the youngest NPD and the given number of NPDs, the Cramer $\mathrm{V}=0.25$ value showed a weakly significant connection $(p=0.012)($ Tab. 6). Those who answered with numbers 10,9 or 11 , gave $82.8 \%$ of the correct answers in connection with the youngest national park. $40 \%$ of those who voted for 10 could name the youngest national park but $55 \%$ of them did not answer. $22.2 \%$ of those who marked 9 or 11 knew the ÖNPD as the youngest national park but $69.4 \%$ of them did not answer. The great majority $(81.8 \%)$ of those who wrote a number with a difference more than one did not answer. The smaller the difference was from the correct number, the smaller the rate of non respondents was. But there was also a big difference of knowledge about the oldest and youngest NPD because the rate of correct answers is smaller in the case of the youngest NPD and the rate of non respondents was much higher in this category.

When I examined the connection between naming the youngest NPD and listing the NPDs the Cramer $V=0.49$ value showed a medium significant connection ( $p=0.001)$ (Tab. 6). $76.5 \%$ of the respondents who could name all the 10 NPDs precisely knew that the Örség was the youngest. A great majority of those $(63.6 \%)$ who listed 9 gave a correct answer. Below these values $6-18 \%$ could name the youngest NPD correctly but most of them in these categories did not even answer (68-100\%). The rate of the wrong answers was between 0 $18 \%$. The value of $\lambda$ is $0.361(\mathrm{p}=0.010)$, which means that the chance that we can guess whether the person knows the youngest national park can be improved by $36.1 \%$, if we know how many directorates he can list correctly.

Table 6 Variables indicating significant connection with the name 'youngest National Park'

\begin{tabular}{|c|c|c|c|}
\hline Criterion & $\chi^{2}$ & Cramer -V & $\mathbf{p}$ \\
\hline Age & 5,038 & 0,195 & 0,081 \\
\hline $\begin{array}{c}\text { Number of National Park } \\
\text { Directorates }\end{array}$ & 16,332 & 0,249 & 0,012 \\
\hline $\begin{array}{c}\text { List of National Park Directorates } \\
\text { NPI-k felsorolása }\end{array}$ & 64,814 & 0,495 & 0,000 \\
\hline
\end{tabular}

Source: edited by author 
We can conclude that the recognition of the oldest national park is more of the part of general knowledge and even those who do not know national parks very much could name it correctly. The recognition of the youngest NPD reflects a deeper knowledge because people who could name it (64-77\%), could list the NPDs correctly or almost correctly. Those who could list 8 NPDs the rate of mistakes is rather high, (15\% of them could give a correct answer) and the rate of non respondents also increased (from the previous $18-36 \%$ to $73 \%$ ).

I was given a mostly correct answer (66.6\%) to the question: 'Which national park directorates is located closest to your place of living?' (Fig. 5). Regarding evaluation this question took up most of the time because in personal questions first I connected the place of living to the county and then to the NPD and I compared this with the answers to this question. The reason for this is that I did not want to influence the answers in any way. 80 people knew which NPD territory they lived in, 22 people (16.7\%) gave the wrong answer, however most of them could determine the geographical area but they had problems with the name of the directorate, I had to face this problem at the $2^{\text {nd }}$ question too. 30 people did not answer.

Figure 5 The distribution of naming the national park directorate nearest to the place of living

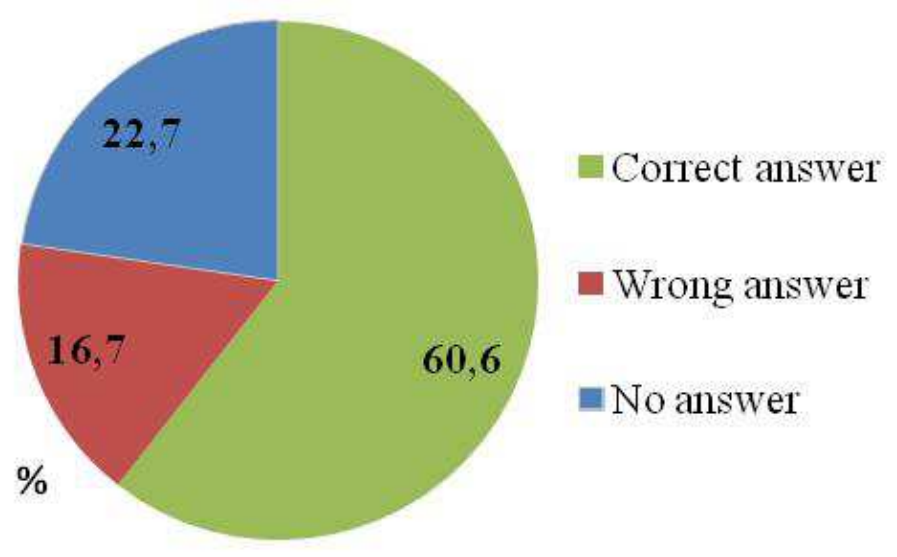

Source: edited by author

Naming the closest national park directorate does not depend on any other variables, only on the respondent's place of living - as I have expected I - this connection is indicated by the significant value of the Pearson $\chi^{2}$.

When I examined the connection between naming the closest national park directorate and the place of living, the Cramer $\mathrm{V}=0.47$ value showed a medium significant connection $(\mathrm{p}=0.000)$ (Tab. 7). At least half of the respondents knew which national park territory their place of living was located in. Zala (62,1\%), Somogy (55,6\%), Baranya (50\%), Vas (90 \%), 
Veszprém (83,3\%), Csongrád (50\%), Tolna (50\%), és Bács-Kiskun (50\%). Most wrong answers came from the inhabitants of Zala and Somogy counties, while three quarters of the inhabitants of Komárom-Esztergom and Pest counties did not even answer. The value of $\lambda$ is $0.231(\mathrm{p}=0.004)$, which means that the chance that we can say about somebody correctly that he knows his local NPD can be improved by $23.1 \%$ if we know where he lives.

Table 7 Variables indicating significant connection with the name 'closest National Park to the place of living'

Source: edited by author

\begin{tabular}{|c|c|c|c|}
\hline Criterion & $\chi^{\mathbf{2}}$ & Cramer $-\mathbf{V}$ & $\mathbf{p}$ \\
\hline Place of living & 59,399 & 0,474 & 0,000 \\
\hline
\end{tabular}

My next question was: 'Could you list sights and attractions in your local national park directorates?' The name of the NPD and its sights were not needed, I simply wanted to get information about the region of their homes. More than half of the respondents ( 74 people, $56.1 \%$ ) could name the sights of their place of living, however 54 people (41\%) got frightened of the question and did not answer (Fig. 6). Listing the sights has no significant connection with any other variables.

Figure 6 Distribution of listing the sights of the National Park close to the place of living

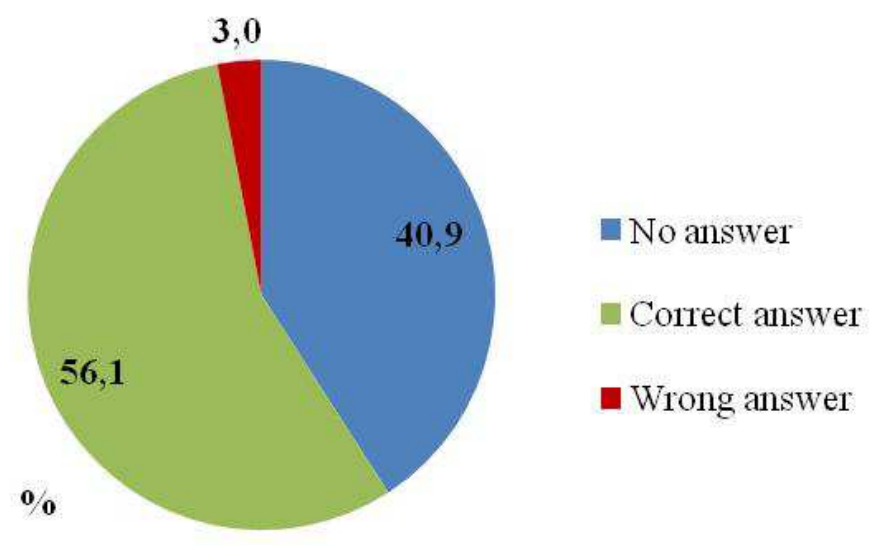

Source: edited by author

2. Students at the Georgikon Faculty go hiking and most of them prefer individual programs

The second part of my questionnaire focused on information about hiking habits. The question 'Do you go hiking?', was not answered by 1 person, 15 people (11.4\%) never go hiking, however $87.9 \%$ (116 people) of the respondents do (Fig. 7). There is not any variable that shows significant connection with hiking habits. 
Figure 7 Do you go on outings or hiking?

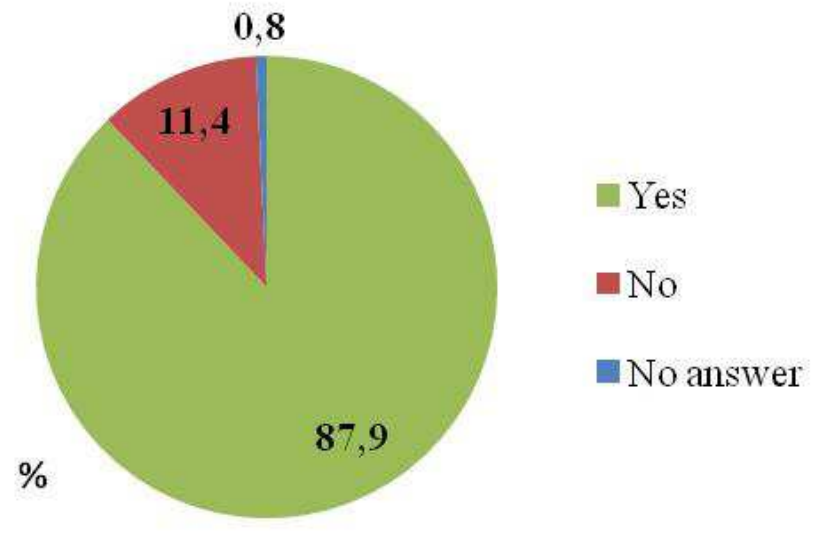

Source: edited by author

Next question: 'If you do, do you prefer organized trips or individual relaxation?' The results are as follows: 12 people $(9.1 \%)$ prefer organized trips, while the majority, 89 people (67.4\%) like individual trips and $12 \%$ is fond of both individual and organized trips alike (Fig. 8). The majority of students do not seem to rely on other people to organize the trip, they do it individually.

The preference of organized and individual trips does not depend on any variables only on the fact whether the respondent go hiking regularly or not, the connection is indicated by the Pearson $\chi^{2}$ significance value.

Figure 8 Distribution of the preferences of organized trips or individual trips

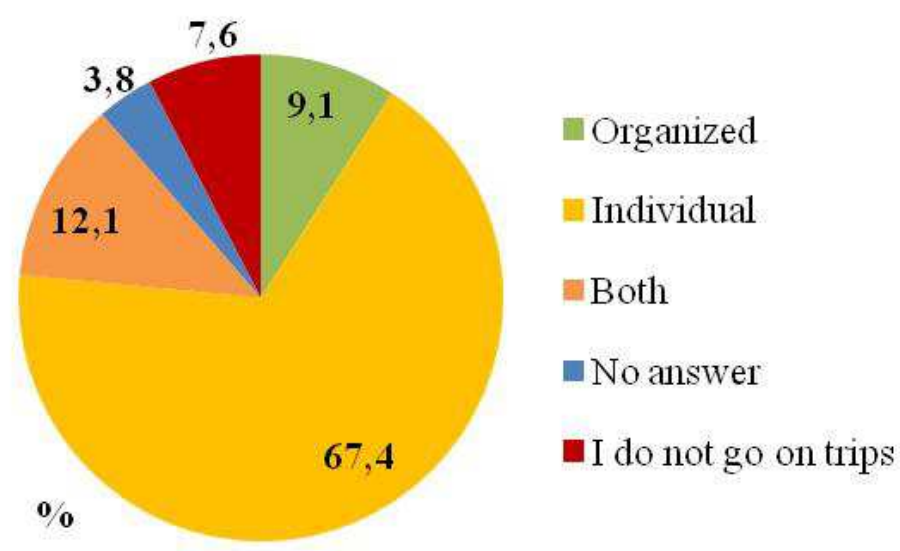

Source: edited by author

When I examined the connection between the preference of organized and individual trips and hiking habits the Cramer $\mathrm{V}=0.69$ value showed the upper level of a medium strong connection ( $p=0.000)$ (Tab. 8). According to some sources this connection is rated as very strong. $9.5 \%$ of those who like hiking prefer organized trips, $75.9 \%$ likes individual forms and 
$13.8 \%$ cannot make a difference. People who do not go hiking regularly $(66.7 \%)$ do not prefer either of the two. Examining the $\lambda$ values, if hiking is our dependent factor, its $\lambda$ value is $0.750(\mathrm{p}=001)$ that is our chance to evaluate the person's hiking habits can be improved by $75 \%$ if we know which form of hiking he prefers. The cause-effect relation is obvious if someone prefers organized or individual trips he probably goes hiking more or less frequently. If the chosen form is the depending factor the value of $\lambda$ is $0.233(p=0.003)$, which means that our chance to say about somebody whether he likes organized or individual trips can be improved by $23.3 \%$ if we know whether he goes hiking regularly or not.

Table 8 Variables indicating significant connection with organized or individual hiking trips

Source: edited by author

\begin{tabular}{|c|c|c|c|}
\hline Criterion & $\chi^{2}$ & Cramer -V & p \\
\hline $\begin{array}{c}\text { Do you regularly go } \\
\text { hiking }\end{array}$ & 127,994 & 0,696 & 0,000 \\
\hline
\end{tabular}

3. The students of the Georgikon Faculty do not often take part in the programs the national park directories offer

My next question: Do you take part in the programs organized by the national park directorates? 'The result is not surprising the previous answers showed that $9 \%$ of the hikers (11 people) like organized trips. Only 13 people, $11.2 \%$ of the hikers and $9.8 \%$ of the interviewees have ever taken part in programs organized by the national park directorates (Fig. 9).

Figure 9 Distribution of the participation in programs organized by the National Park Directorate

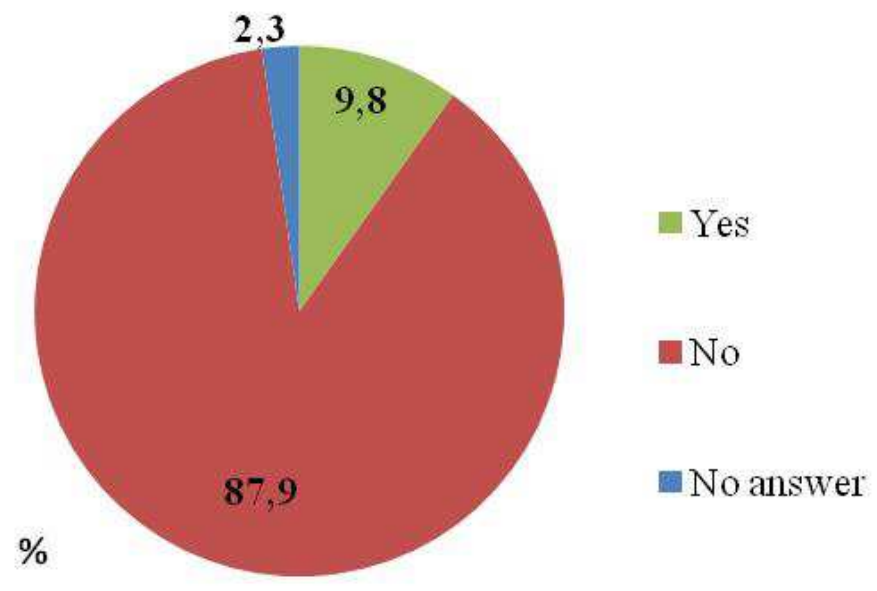

Source: edited by author 
My last question: 'If you do, what kind of programs do you take part in and how often?' It was a relevant question for only 13 people. There was only one person who could be regarded eco-tourist following the real sustainable aspect, because he takes part in the different programs organized by the national park directorate monthly, for example eco trips, bird ringing, rescuing frogs and lectures. He is the so-called hard eco-tourist (Weaver, 2005). The other 12 people take part in organized trips like these once a year mostly in hiking, camps and bird watching. The main aim for most of them is the excursion ( 9 people). They are the so-called soft eco-tourists (Weaver, 2005).

\section{DISCUSSION}

1. The knowledge of the students in Georgikon Faculty about national parks is insufficient before starting their studies in this field.

$40(30.3 \%)$ students out of 132 respondents knew correctly that we have 10 national park directories but only 17 students $12.9 \%$ of the respondents could list them correctly. The question: which is our oldest and youngest national park remained unanswered by more than $60 \% .36$ students (27\% of the respondents) answered correctly that Hortobágy National Park is the oldest and 29 of them (22\%) knew that the Örség National Park is the newest. $60.6 \%$ could identify the national park in their own place of living. Very often the official name was the problem and not the geographical location. More than half of the respondents $(56 \%)$ could list supply elements in the directory of the park in their settlement. Knowledge is really insufficient but youths have a lot of information about national parks, on average they can list half of the national parks.

2. Students in the Georgikon Faculty go hiking regularly and the majority of them like individual relaxation.

According to the questionnaire survey youths like hiking $(87.9 \%)$ and the majority of them (67.4\%) prefer individual relaxation to organized trips.

3. The students of the Georgikon Faculty do not often take part in the programs the national park directories offer.

One fifth of the responding youths go hiking in organized trips therefore it is not surprising that only few of them $(9.8 \%)$ took part in the programs organized by the national park directories. 


\section{CONCLUSION}

The results of the study show that taking aim at the future eco-tourists, the present young adult age group is an important task. Young people have a lot of knowledge about national parks, they like relaxing outdoors but the programs organized by the national park directorates are not very popular with them. In my opinion aimed marketing and special programs could increase the young people's interest. These organized programs should be more attractive or alternative program opportunities should be offered where they can select their own program packages to provide a sense of individuality.

\section{REFERENCES}

Ahmad, A. (2014). The disengagement of the tourism businesses in ecotourism and environmental practices in Brunei Darussalam. Tourism Management Perspectives. 10.

Babbie, E. (2008). A társadalomtudományi kutatás módszertana, Balassa Kiadó, Budapest.

Cousins, J. A. (2007). The role of UK-based conservation tourism operators. Tourism Management. 28.

Katotás, Zs. (Ed.) (1996). Nemzeti parkjaink, jelen és jövő. Aqua Kiadó, Budapest.

Kalotás, Zs. (2004). Nemzeti parkok Magyarországon - Természet és táj. Alexandra Kiadó, Pécs.

Kalotás, Zs. (2005). A Duna-Dráva Nemzeti Park. A folyók felségterülete. Alexandra Kiadó, Pécs.

Kalotás, Zs. (2008). Körös-Maros Nemzeti Park. A természet szigetei. Alexandra Kiadó, Pécs.

Kalotás, Zs. (2012). A Kiskunsági Nemzeti Park. A víz és szél formálta táj. Alexandra Kiadó, Pécs.

Kapocsy, Gy. (1993). Nemzeti parkjaink. Officina Nova Kiadó, Budapest.

Környezetvédelmi és Vízügyi Minisztérium, Természetvédelmi Hivatal (KVvM) (2005). A természetvédelem ökoturisztikai koncepciója.

Lengyel, M. (1998). Ökoturizmus és marketing, Magyarország az ezredfordulón MTA stratégiai kutatások - 24. füzet, Zöld Belépő, BKE Környezetgazdaságtani és technológiai tanszék, Budapest.

Lindberg, K. \& Hawkins, D. E. (1993). Ecotourism. A Guide for Planners and Managers, The Ecotourism Society, North Bennington, Vermont.

Majoros, P. (2004). A kutatásmódszertan alapjai, Perfekt Nyomda, Budapest.

Malhotra, N. K. \& Simon J. (2009). Marketingkutatás, Akadémia Kiadó, Budapest.

Mintel (2014). Redefining Ecotourism. London, United Kingdom.

Országos Ökoturizmus Fejlesztési Stratégia (OÖS)(2008). Pannon Egyetem, Turizmus Tanszék - Aquaprofit Zrt. Veszprém-Budapest.

Sulyok, J. (2001). Ökoturizmus. Turizmus Bulletin, 2001/4. szám.

Sulyok, J. (2014). Az ökoturizmus helyzete Magyarországon. Turizmus Bulletin. 2014/2.

Tóth, É. (2007). Az ökoturizmus jelentőségének vizsgálata Duna-Dráva Nemzeti Park drávai szakaszán, XXVIII. Országos Tudományos Diákköri Konferencia, Debrecen.

Tóth, É. \& Kocsondi, J. (2008). Ökoturizmus a nemzeti parkok életében. XI. Nemzetközi Tudományos Napok, Károly Róbert Főiskola, Gyöngyös. 
Tóth, É. \& Kocsondi, J. (2010a). Ökoturisztikai felmérés a Duna-Dráva Nemzeti Parkban 2009-ben, XII. Nemzetközi Tudományos Napok, Károly Róbert Főiskola, Gyöngyös.

Tóth, É.(2010b). Turisztikai vizsgálatok a Duna-Dráva Nemzeti Parkban, XVI. Ifjúsági Tudományos Fórum, Keszthely.

Tóth, É. \& Lukács, G. (2013). A Dráva-mente ismertsége 2013-ban, LV. Georgikon Napok: A jövő farmja. Keszthely.

Vojnits, A. (2006). Magyarország nemzeti parkjai. Budapest, Corvina Kiadó.

Vidékfejlesztési Minisztérium (VM) (2014a). Bemutatóhelyek, programok 2014. Élmény? Természetesen. Magyar Nemzeti parkok. Kiadja: VM, 2014. január. Közremüködő: NAKVI .

Vidékfejlesztési Minisztérium (VM) (2014b). Nemzeti Parki termékek. Egy szelet hagyomány. Magyar Nemzeti parkok. Kiadja: VM, 2014. május. Közremüködő: NAKVI .

Weaver, D. B. (2005). Comprehensive and Minimalist Dimension of Ecotourism. Annals of Tourism Research 32.

Weaver, D. B. \& Lawton, L. J. (2007). Twenty years on: The state of contemporary ecotourism research. Tourism Management. 28.

347/2006. (XII. 23.) Korm. rendelet a környezetvédelmi, természetvédelmi, vízügyi hatósági és igazgatási feladatokat ellátó szervek kijelöléséről. /Magyar Hivatalos Jogszabálytár, 2013/8. Magyar Közlöny Lap-és Könyvkiadó/.

14/1997. (V. 28.) KTM rendelet a nemzeti parkok területének övezeti kategóriákba való besorolásáról. /Magyar Hivatalos Jogszabálytár, 2013/8. Magyar Közlöny Lap-és Könyvkiadó/.

www.ecotourism.org

http://sdt.unwto.org/content/ecotourism-and-protected-areas 